ACTA UNIVERSITATIS LODZIENSIS

FOLIA LITTERARIA POLONICA 5(35) 2016

http://dx.doi.org/10.18778/1505-9057.35.04

Barbara Sobczak* $^{*}$

\title{
News as a Rhetorical Act
}

\section{Terminology}

The article opens with an explanation of the basic terminology. The term "news" is treated as a "coverage of an incident". Such a treatment refers to the distinction between news and an event that was formulated by Wilbur Schramm in his work entitled The Nature of $\mathrm{News}^{2}$. For Schramm, news is not the same as an incident, but it is something that follows the event. This is a crucial issue because the concept functions also as an "extraordinary event, a piece of new information"3 both in everyday life and in media research. Additionally, I assume that an account of an event - in order to become news - has to be disseminated by the media and become a public act ${ }^{4}$. In relation to these arrangements, TV news is an account of an event. It usually consists of a preview ${ }^{5}$ and short footage (in Poland sometimes referred to as a TV feuilleton), which is the result of a reporter's

* Dr., e-mail: barbarasobczak@o2.pl, Adam Mickiewicz University in Poznań, Faculty of Polish and Classical Philology, Institute of Polish Philology; ul. Fredry 10, 61-701 Poznań.

${ }^{1}$ This way of understanding "news" is adopted by the media researchers (See: I. Tetelowska, „Informacja jako odrębny gatunek prasowy”, in: eadem, „Szkice prasoznawcze”, Ośrodek Badań Prasoznawczych, Cracow 1972, p. 237; J. Fras, „Dziennikarski warsztat językowy”, Wydawnictwo Uniwersytetu Wrocławskiego, Wroclaw 1999, p. 78; W. Furman, A. Kaliszewski, K. Wolny-Zmorzyński, „Gatunki dziennikarskie. Specyfika ich tworzenia i redagowania”, Wyższa Szkoła Zarządzania w Rzeszowie, Rzeszow 2000, p. 33; but also M. Palczewski, „Cała prawda o newsie. Definicja - granice poznania - konteksty”, in: „Teorie komunikacji i mediów”, Vol. 4, ed. M. Graszewicz, J. Jastrzębski, Oficyna Wydawnicza Atut, Wroclaw 2011, p. 54).

${ }^{2}$ W. Schramm, "The Nature of News", Journalism Quarterly 1949, No. 26, p. 259.

${ }^{3}$ Monika Worsowicz, among others, also writes about it: "In everyday speech to «have news» means to have a message, a new message, especially an extraordinary one, surprising" (M. Worsowicz, „«Mam newsa!», czyli o problemie naukowców i marzeniu dziennikarzy”, in: „News wobec wyzwań XXI wieku”, ed. M. Palczewski, M. Worsowicz, Akademia Humanistyczno-Ekonomiczna, Lodz 2010, pp. 9-24).

${ }^{4}$ M. Palczewski, op. cit., p. 54.

${ }^{5}$ In the journalist jargon it is a so called "lead-in" - an introduction read by a newscaster in a TV studio. 
work, and broadcast on television, usually as one of the elements of a news magazine structure, but also as an element of a news station programme. The film footage is not an invariant news element as there are reports without footage, although these are scarce. Despite the fact that TV news is a closed thematic and structural entity, it usually does not function on its own. It is part of a larger project, and, as such, it exists in a system of news (for example within the structure of a news magazine), which is significant because the context influences the meanings and the way the messages are interpreted.

A rhetorical act is understood as a usage of symbolic means (including language and image) in order to achieve an intended aim. I assume that to qualify an act as a "rhetorical" one, it has to be intended, it has to be a response to a specific situation (certain historical, political or cultural factors have to occur, as these should be a pretext for the act to happen), and finally it has to be addressed to the recipients ${ }^{6}$. Rhetoric is a process in which, by means of a language and other symbolic measures, an experience is organized and conveyed to other people. It happens, however, in order to achieve pre-planned effects? It is, thus, a process focused on persuasion ${ }^{8}$, and the choice of the measures depends on the one who speaks, for what purpose, and in what circumstances.

\section{The aim of news}

Conveying information about something is the most important aim of news. The information can refer to a single event or many incidents, as well as to processes, phenomena or concepts. This aim is exposed by the context in which news is "used". As stated before, it is usually broadcast as part of a news magazine. Here, the word "news" refers to the notifying function of informing about events9. It has its own pragmatic effects. It requires the informative publication to be devoid of subjective forms of expression, to aim at full objectivity (underlining the impartial-

\footnotetext{
${ }^{6}$ See: K.K. Campbell, S.S. Huxman, T.R. Burkholder, "The Rhetorical Act. Thinking, Speaking and Writing Critically", Wadsworth, Belmont 2003, pp. 27-28.

${ }^{7}$ See: K.K. Campbell, "Modern Rhetoric", in: "Encyclopedia of Rhetoric”, ed. T.O. Sloane, Oxford University Press, New York 2001.

${ }^{8}$ Aristotle also indicated persuasion as the aim of rhetoric, stating that rhetoric "may be defined as the faculty of observing in any given case the available means of persuasion" (Arystoteles, „Retoryka”, in: idem, „Retoryka. Retoryka dla Aleksandra. Poetyka”, transl. H. Podbielski, Wydawnictwo Naukowe PWN, Warsaw 2004, p. 47, 1355b).

9 J. Maziarski, „Informacja”, in: „Encyklopedia wiedzy o prasie”, ed. J. Maślanka, Ossolineum, Wroclaw 1976, pp. 107-109; Z. Bauer, “Gatunki dziennikarskie”, in: „Dziennikarstwo i świat mediów”, ed. Z. Bauer, E. Chudziński, Universitas, Cracow 2000, pp. 143-173; M. Wojtak, „Gatunki prasowe", Wydawnictwo Uniwersytetu Marii Curie-Skłodowskiej, Lublin 2004, pp. 29-33.
} 
ity of the broadcaster - the journalist ${ }^{10}$ ), and, primarily, to highlight the cognitive functions. It is emphasised that the goal of information is to present phenomena, in contrast to journalism, which is to comment on them ${ }^{11}$. Some scholars, such as Walery Pisarek, add that information, in order to be comprehensive, has to answer the following questions: who?, what?, where?, when?, why?, and to what effect? ${ }^{12}$

It can be thus stated that the dominant news function should be the informative one, the docere function. It is impossible, however, when talking about news, to ignore the mechanisms which decide what becomes its subject, why it happens, and in what way it informs about the world. As media research shows ${ }^{13}$, news programmes enjoy a high status among media communications, and are one of the most important sources of knowledge about the present situation in the world. News is a tool used to navigate the recipient's attention, to set a certain order, and to attach meaning to the way they experience and understand the world. The gatekeeping activities are of paramount importance here - these are the selection of information and focusing the recipient's attention on the selected fragments of reality. The figure of the synecdoche is extremely important in this context. News, instead of showing the whole, presents only a part of it, and it is crucial for the fragment to convey the essence of this entity, and not to deform it. When it comes to TV communication, the suggestive audiovisual form is also of importance, as by means of an image, it allows the creation of the recipient's belief that they are not only informed about the present situation, but also that they observe the reality and take part in the events to which they have no access. According to Pierre Bourdieu, the image has a peculiar ability to create the "reality effect"14. Television makes people believe in what they see, in what is broadcast. They believe that when watching news they get to know the facts. Facts are understood as "a synonym of something that exists, happens or has already happened"15. As Marek

${ }^{10}$ M. Szulczewski, „Informacja”, in: „Teoria i praktyka dziennikarstwa. Wybrane zagadnienia”, ed. B. Golka, M. Kafel, Z. Mitzner, Państwowe Wydawnictwo Naukowe, Warsaw 1964, pp. 91-97.

${ }^{11}$ W. Furman, A. Kaliszewski, K. Wolny-Zmorzyński, op. cit., p. 26.

${ }^{12}$ W. Pisarek, „Podstawy retoryki dziennikarskiej”, in: „Dziennikarstwo i świat mediów. Nowa edycja”, ed. Z. Bauer, E. Chudziński, 4. ed., rev., exp., up. ed., Universitas, Cracow 2008, p. 371. See: also: J. Liberek, „Informacja czy manipulacja? Jak Gazeta Wyborcza pisze o Kościele”, Więź 1992, No. 11, pp. 21-25; A. Zwoliński, „Słowo w relacjach społecznych”, WAM, Cracow 2003, pp. 204-210.

${ }^{13}$ M. Lisowska-Magdziarz, „Media powszednie. Środki komunikowania masowego i szerokie paradygmaty medialne w życiu codziennym Polaków u progu XXI wieku”, Wydawnictwo Uniwersytetu Jagiellońskiego, Cracow 2008, p. 174; L. Miś, „Demonstracje retoryczne w telewizyjnym programie informacyjnym «Fakty» - TVN”, in: „Sztuka perswazji. Socjologiczne, psychologiczne i lingwistyczne aspekty komunikowania perswazyjnego”, ed. R. Karpiel, K. Leszczyńska, Zakład Wydawniczy Nomos, Cracow 2004, pp. 323-324.

${ }^{14}$ P. Bourdieu, „O telewizji. Panowanie dziennikarstwa”, transl. K. Sztandar-Sztanderska, A. Ziółkowska, ed. M. Jacyno, Wydawnictwo Naukowe PWN, Warsaw 2009, p. 47.

${ }^{15}$ M. Karwat, „Medialna mitologia faktów”, in: „Współczesne oblicza mediów”, ed. J. Marszałek-Kawa, Wydawnictwo Adam Marszałek, Torun 2005, p. 45. 
Palczewski ${ }^{16}$ says: it is obviously one of the myths concerning news, as facts - and it was already scientifically discussed - are not observer independent, neutral, they are not objectively or permanently delivered. Facts are interpretations of the events. They always correspond with some systems of values, they undergo selection and their different nuances are variously favoured. Finally, they are described by means of a language (even if these are images), and as such they consist of an emotional and axiological weight ${ }^{17}$. In news, the audience observes only a version of reality, which (by means of a selection and interpretation of the information) is presented by the broadcaster. And hereby lies the hidden potential of news:

by means of the extraordinary power granted by the image, TV journalists can create unparalleled effects... . This power of presentation can result in mobilisation. It can bring to life not only ideas and presentations, but also groups. Little sensations, everyday incidents or occurrences can influence the political and ethical implications, they can evoke strong emotions ${ }^{18}$.

It is a political decision of the media broadcaster which events become the news subject. Some pieces of information are omitted, even though they fulfil the criteria of topicality or they are sensational and publicly important. Pieces of information inconvenient to various interests, the government, the owner of the media or simply the supervisor are not conveyed. Such instances are described as examples of media manipulation (the so-called silence ${ }^{19}$ ), however, it also happens that some events and their importance are purposefully publicised and highlighted ${ }^{20}$.

News creates a certain vision of the world, but it also wants the recipient to unconditionally accept this vision, adopt the presented judgements and opinions, and, in order to achieve this, it uses various authenticating strategies. The movere and delectare functions surface in this sphere.

The aim of news is, thus, to convey information. Nevertheless, its aim is also to:

- create an image of the world by selection of topics, information and of the way the reality is presented (the creational function of news ${ }^{21}$ );

\footnotetext{
${ }^{16}$ M. Palczewski, op. cit., pp. 55-56.

${ }^{17}$ Ibid., p. 56.

${ }^{18}$ P. Bourdieu, op. cit., pp. 46-47.

${ }^{19}$ M. Iłowiecki, „Krzywe zwierciadło. O manipulacji w mediach”, Wydawnictwo Archidiecezji Lubelskiej Gaudium, Lublin 2003, p. 114.

${ }^{20}$ M. Czyżewski, K. Dunin, A. Piotrowski also wrote about the SEP concept (Somebody else's problem) and its reversal, which is publicising irrelevant things in the media („Cudze problemy. O ważności tego, co nieważne. Analiza dyskursu publicznego w Polsce”, Wydawnictwa Akademickie i Profesjonalne, Warsaw 2010).

${ }^{21}$ Janusz Gajda distinguishes five culture-making functions of the media: the function of popularising various messages, the stimulating function (achieved by stimulating the audience to
} 
- convey certain models to follow, and even educate one on how one should live (model-making function). News shows "heroes" and "antiheroes" of everyday life. This footage shows individuals who saved other people risking their own lives, who helped in natural disasters, accidents, or conversely - who ignored critical situations, and for example did not help the victim of an attack;

- stimulate recipients to behave in a certain way, provoke reflection, give a sense of social connection by means of presenting subjects relevant to certain social groups, with which the spectator can identify (the stimulating function). People are shown in difficult situations - fighting off illness, after an accident, after a natural disaster like fire or flood. Such communications are at the same time an indirect call for help on behalf of the victims;

- evaluate events (the evaluating function). The assessment can be formed in two ways: directly - as the author's comments (usually during a stand-up or by means of a quote) presented as short utterances in front of a camera; or indirectly by means of the way the subject is presented. It can happen, for example, through irony, which allows the recipient to surmise an additional meaning to the journalist's direct message, or by means of a hyperbola - when events are overplayed, presented as a reflection of a distorting mirror in order to achieve the satirical effect;

- and finally, to give pleasure (the delectare function). This function can also be implemented in two ways: by the selection of topics - for example when one reports about fashion manifestations on the red carpet during the Academy Awards, about disco-polo - the Polish music genre, or Internet memes; but also by the style of the message, when one presents the quasi-cabaret convention of communication with the recipients, not necessarily when talking about some humorous issues. Political information more and more often is supplemented with film citations, for example, from the films of such authors as Stanisław Bareja or Juliusz Machulski.

\section{News and the recipient's needs}

Looking at news from the rhetorical perspective, one has to ask: to what critical situation (on Lloyd Blitzer's understanding ${ }^{22}$ ) and to what needs does it respond? Andrzej Kudra ${ }^{23}$, when he tried to define news, presented a thesis that

\footnotetext{
an active reception and a more intense participation in the culture), the model-making function (it promotes the model of behaviour), the interpersonal function (fulfilled by the omnipresence of the media, thanks to which people can get to know the lives of others), and the ludic function (See:

J. Gajda, „Media w edukacji”, Oficyna wydawnicza Impuls, Gdansk 2007).

${ }^{22}$ L.F. Bitzer, “The Rhetorical Situation”, Philosophy \& Rhetoric 1968, No. 1, pp. 1-14.

${ }^{23}$ A. Kudra, „News jako funkcja”, Acta Universitatis Lodziensis. Folia Literaria Polonica 2010, No. 13, pp. 401-403.
} 
in the communicational aspect information falls within the ambit of authoritarian communication or the communication of the communicational dictate. It means that the message has to appear. A recipient awaits the message which has to fulfil its informational functions. Research conducted by Małgorzata Lisowska-Magdziarz confirms this thesis, as the scholar explains that the social compulsion to be informed is a vital factor. Being informed is a type of cultural responsibility, and television is one of the most common sources of such knowledge ${ }^{24}$, especially for middle-class recipients, who have a smaller cultural capital ${ }^{25}$. Television spreads knowledge of crucial events, but it also conveys information important for one's work, education, entertainment and social functioning. Many people are entirely dependent on television when it comes to gaining knowledge, that is why it has a certain monopoly on shaping human mindsets ${ }^{26}$. The recipient needs knowledge and news fulfils this need. Nevertheless, one has to remember that knowledge conveyed by means of news is not episteme (referring to the platonic division). This means that it is not certain and justified, not based on intellective cognition, but it is doxa - a presumption, an unreliable cognition, consisting of possible mistakes and refutable beliefs ${ }^{27}$. Knowledge based on news is essentially of short duration - news quickly gets old and almost the moment it is published it loses its topicality. This knowledge is also superficial, as the conditions of communication, primarily the time restrictions, do not allow full analysis of the phenomena. It is also simplified - again: the determinants of communicational situations are of paramount importance, as a journalist, when creating communications, one has to take into consideration the recipient's mental abilities and their ability to understand the TV communications. That is why news increasingly deals with single or a few connected events instead of phenomena, processes or concepts. News focuses on what is topical, not taking into account the historical and structural reasons or the broader context of the social and political environment, nor the processes that occur within ${ }^{28}$. Talking about phenomena and concepts requires

\footnotetext{
${ }^{24}$ Research conducted by TNS Polska shows that even though the number of Internet users is constantly increasing, $76 \%$ of the Poles still watch television daily (http://www.tnsglobal.pl/ informacje/telewizja-trzyma-sie-mocno-nowe-urzadzenia-przynosza-nowe-wzorce-ogladaniainfografika/ [access: 21.03.2015]). Other research by TNS Polska proves that the main sources of daily information for the respondents are „Wiadomości” on TVP1 channel (22\%) and „Fakty” on TVN channel (20\%) (http://wyborcza.pl/1,76842,15095765,Dla_60_proc_Polakow_TVP_jest_ dobra_telewizja_publiczna_.html [access: 21.03.2015]).

${ }^{25}$ The higher the recipients' education and the richer the social contexts - the more extensive the criticism of the media information, and the stronger the emphasis they put on other sources of knowledge and current affairs (M. Lisowska-Magdziarz, op. cit., pp. 174-179).

${ }^{26}$ P. Bourdieu, op. cit., p. 43.

${ }^{27}$ M. Palczewski, op.cit., p. 59-60.

${ }^{28}$ A news broadcast dated 20 March 2015 on TVN24 channel can serve as an example of such a simplification of the reality. Its topic revolves around the exams at a certain point of education in India, the text is supported with footage, which shows people climbing the walls of a building
} 
advanced cognitive competences, whereas talking about events - only following the action carefully ${ }^{29}$.

Finally, this knowledge is selective. News is created as a reaction to a situation, an event, but it has to be a unique event - different, extraordinary, unusual. This exceptionality can refer to something abnormal, even deviant; but it can also result from the importance of the event, its significance for a community when it concerns influential people or the majority. For decades journalistic practice and the media deontology have been creating criteria indicating what kind of events can or should serve as a pretext to be presented in the media. Most of these criteria have been imported from the press. It has been adopted that the event - in order to become news - has to be: 1) unique - according to Bourdieu news magazines have to present extraordinary events on an ordinary, daily basis $\left.{ }^{30} ; 2\right)$ of short duration; 3) up-to-date - it has to occur between the consecutive news broadcasts; 4) important for the recipient; 5) predictable and desirable or 6) sudden and unexpected; 7) repetitive; 8) in contrast with other information; 9) relating to social elites, 10) relating to countries which play an important role in politics, and finally: 11) personalised and 12) negative ${ }^{31}$. These criteria take into consideration the potential interests of the TV recipients. As media research ${ }^{32}$ and psychologists' experience show, people are mostly interested in what is close to them - that is why news more often presents local events instead of foreign ones; it presents what is specific and close to an individual's experience. That is why news shows problems of a general nature on the basis of examples of ordinary people (socalled personalisation) - it shows what is real, that is what has really happened,

and passing little pieces of papers through windows: "Cheating in exams is very common in India. However, the creativity of high school students in Bihar state - and their parents - surpassed all other achievements. Teachers caught hundreds of students who tried to bring not only cheat sheets but whole books to the exam room. Students' parents and friends climbed the school walls to give the crib sheets through windows. This year almost 1.5 M students in over 1,200 schools in Bihar state are taking an exam at the end of the $10^{\text {th }}$ grade. Students are under a great pressure, as in order to continue their education they have to pass this exam". The issue was treated as a sensational curiosity, however, presenting the context would make it possible to say something more about the cause of such behaviour, and even transform the character of the described event. The social and demographic situation in India was not included, nor was the high motivation behind such behaviour, which, unimaginable in Poland or in Europe, is based on the enormous job market competition. The results of the exam decide the child's future in a country, where there are, on average, 10 thousand applicants for 1 post in the civil service.

${ }^{29}$ It was Maciej Mrozowski who pointed out this news quality, which is typical for the Polish news, as he compared Polish, German, British and French reports. The Polish news is usually a factual presentation - it conveys one or several events, whereas news from different countries is an analysis of processes and phenomena (M. Mrozowski, „Telewizyjne programy informacyjne polskie i zagraniczne (analiza porównawcza)", Studia Medioznawcze 2009, No. 3, pp. 37-38).

${ }^{30}$ P. Bourdieu, op. cit., p. 46.

${ }^{31}$ J. Fras, op. cit., p. 78

${ }^{32}$ W. Pisarek, op. cit., p. 369. It is clear that some of the criteria are mutually exclusive. 
and not what could have happened; what is conflictive instead of what is harmonious; what is new and unexpected, as well as cheerful and funny, instead of what is grave and serious. That is why infotainment is becoming so popular.

After all, the news knowledge is not verifiable, especially for the recipient, and this opens dangerous possibilities of coaxing abuse and even of manipulation. In the traditional culture it seemed that the differentiation between what is true and what is false, what exists and what does not, was simpler because the culture and values were constructed from the same perspective, from the point of view of the groups that held power. Today there is not one measure of broadcasting. There are many media, each of them constructs a different story about the world, and it is impossible for the media recipient to verify "where the truth lies". It is interesting that certain voices are raised socially and they refer to some TV channels lying more than others, and to some channels being more truthful. A casus showing the audience of the Trwam channel can be presented. These people will say that the channel TVN lies, however, they will not state that the channel Polsat lies or that TVP1 lies. During the times of the Polish People's Republic (Polish: Polska Rzeczpospolita Ludowa, PRL) the situation was clearer - no one trusted the media, because the media were perceived as the government's instrument. The recipient's belief in the broadcaster's truthfulness is crucial in this context. In order to build such a belief, to uphold or strengthen it, the media broadcaster reaches for three sources: measures coming from the communication (logos), the broadcaster's authority (ethos) and the recipient's emotions (pathos).

News also fulfils other needs of the recipients. Roger Silverstone ${ }^{33}$, when analysing the systematic pattern of everyday activities, described also a need for continuity. The repetitiveness of some actions, including methodical watching of the TV news, gives people a sense of constancy and steadiness of the external world. The need for continuity protects against the dangers resulting from the variability of the surrounding reality and from fears connected with increasingly stressful life. Of course, on the one hand, the news evokes fears because negative information is shown, but on the other one, these programmes try to dispel such concerns. The knowledge that one can go to sleep peacefully, because one knows one will not experience a meteor shower during the next few hours is crucial. There is an interesting observation by Klaus B. Jensen, which stems from his research on the role of the political news in people's lives. Watching news gives people a sense of control over what is happening in the distant reality, even though they have no influence on it ${ }^{34}$. Even the formula of the news magazine is important for the sense

${ }^{33}$ R. Silverstone, "Television and Everyday Life", Routledge, London 1994, as cited in: S. Allan, „Kultura newsów”, transl. A. Sokołowska, Wydawnictwo Uniwersytetu Jagiellońskiego, Cracow 2004, p. 116.

${ }^{34}$ K.B. Jensen, "The Social Semiotics of Mass Communication", Sage Publications, London 1995, p. 85. 
of continuity. These are a predictable structure to the programme and a fixed broadcast time ${ }^{35}$.

Watching news also fulfils the need for affiliation ${ }^{36}$ and is an instrument used for building social bonds. Watching news includes the recipient in the community created by the broadcaster. Everyone's attention is focused on some selected elements of reality, which become a subject of interest, conversations and afterthoughts. What is more, the formulated communication uses knowledge which is considered common for the whole audience. That is why stereotyping and generalisation are so frequent in the news.

Finally, people watch news for entertainment, for visual pleasure - the news shows images which create a sense of being an eye witness, it shows competent and nice announcers, curiosities from all around the world, as well as sensational, exceptional and peculiar information.

\section{Means of persuasion - influence on the recipient}

The broadcaster's credibility is mostly based on proficiency and trust ${ }^{37}$. When it comes to news, the broadcaster has to be analysed on two levels - in the broad sense it is the media institution, in the narrow sense it is the journalist, the reporter, who makes news. The broadcaster's credibility is thus the credibility of the TV station and of the journalist who presents news, who is seen and heard by the recipient. Proficiency means the perception of the broadcaster as one who has knowledge, experience or who is an authority. On the level of the media institution, this competence is created through the station's self-presentation, where the station emphasises its technological background, its technical abilities to be present where the most important events happen, its reception or its human resources. Such proficiency also results from a specialization. From research conducted by Byron Nass and Clifford Reeves, it stems that information watched on specialized channels is considered more important, more succinct and serious ${ }^{38}$. In the context of the Polish news, stations like TVN24, TVN Biznes i Świat, TVP Info or Polsat News can be considered as such channels. This phenomenon is analogous to the one that is present within interpersonal relations. If a person is labelled "an expert", they are more reliable,

\footnotetext{
${ }^{35}$ S. Allan, op. cit., p. 116.

${ }^{36}$ Abraham Maslow emphasises it as one of the most important needs (idem, „Motywacja i osobowość", transl. J. Radzicki, Wydawnictwo Naukowe PWN, Warsaw 2006, pp. 68-69).

37 J.L. Whitehead, "Factors Of Source Credibility", Quarteley Journal of Speech 1968, No. 54, pp. 59-63.

${ }^{38}$ B. Reeves, C. Nass, „Media i ludzie”, transl. H. Szczerkowska, Państwowy Instytut Wydawniczy, Warsaw 2000, p. 174.
} 
they serve as an authority and other people are more susceptible to their persuasion. It is similar when a medium has the same label. The specialized media are perceived by recipients as more competent. Of course, the labels can differ (there can be for example a "public" label, a "commercial" label or a "Rydzyk" label) and it results in different consequences for the power of the media impact. Nevertheless, on television, the person who is watched by the audience is more important than the credibility of the message (it is different in the press, where, from the point of view of credibility, it is the title, the publisher who is more important than the author of the specific text. It stems from the fact that television emphasises individuality and it happens because of the image). Specialization is a vital factor when it comes to the journalist's proficiency. An attentive news watcher knows that reporters specialize in particular fields. One person prepares materials about political, social and business events, another one talks about the absurdities of the surrounding reality. If one repeatedly hears information about journalist $X$ appearing in the Sejm (the lower house of the Polish parliament), one will eventually consider her as competent and professional in the political sphere. Trust, however, is a derivative of what is based on impressions. In the context of news, it is the recipient's impression of the broadcaster's neutral point of view and not a point of view contaminated with subjectivism and ideology. It is an impression of reliability, factuality, accuracy and of the objectivity of the journalistic practices. It can be achieved though adequate measures within the text, however, the broadcaster's ethos plays a crucial role which strengthens the effectiveness of the persuasion. This ethos consists of a vital element - the social belief in the journalist's public role, as the journalist is to serve society and act on its behalf. Journalism is a profession of public trust. Additionally, journalists, wanting to enhance this trust, use visual measures like their outfit or behaviour, which fit the recipient's expectations concerning their role.

The message is considered true by the recipient when it can be understood. And one understands a message when one is able to draw conclusions from presumptions or because one is familiar with the subject ${ }^{39}$. In news, if something is "true" for the recipients, it means it is concordant with their universal imagination, it refers to the images of the world in their mindsets, to the social relations which connect them, to their beliefs and values. That is why the way one talks about the world represents a certain pattern, it refers to common beliefs and stereotypes. When politics is discussed it is presented as a conflict, a clash of views; when crime is discussed it shocks with emotions and seeks answers to questions like: who killed?, and who could have prevented the crime?; when Christmas is discussed, Santa Claus from Lapland has to be presented. The confidence in truth can be also supported with:

${ }^{39}$ J. Wasilewski, A. Skibiński, „Prowadzeni słowami. Retoryka motywacji w komunikacji publicznej”, Diffin, Warsaw 2008, p. 161. 
- images from the scene of an event and live reports, as to see the event is to believe it;

- argumentation based on experts' quotes (presented as short utterances in front of a camera), but also charts, graphs or research findings;

- arguments built with inductive reasoning. News describes the reality through a series of specific events - from the most detailed to the more general ones;

- applying the factor of the broadcaster identifying with the recipient. In order to do so, certain participants - protagonists - have to appear in the communication, with whom the audience can identify. These are ordinary people who are the victims or the beneficiary of the described events. As Elliot Aronson and Anthony Pratkanis ${ }^{40}$ showed, including a single example can be an effective persuasive measure. It can be far more effective than research results or statistical data.

The way the communication is formulated is an important factor influencing its effectiveness. One has to remember that news, broadcast within news magazines, addresses a vast audience with various communicational competences, who, additionally, receive it when distracted. That is why the structure is so important, and, as Maciej Mrozowski states, it should be maximally adjusted to the recipient's "structure of curiosity" which are the answers to the following questions: what happened?, what caused the event?, what is the possible result?, what are the conditioning and circumstances of the event?, and what is the meaning of the event? These are thus: description, causes, effects, explanations and comments. However, the composition in itself is not enough. Journalists use many measures which serve to attract and excite the attention of the audience. These are both verbal and visual measures focused on evoking a certain emotional state or attitude towards the message. These are, for example, figures which serve engagment in dialogue: rhetorical and subiectio questions, emotionally loaded vocabulary, metaphors and analogies, which explain the described objects and influence the intelligibility of the communication, irony, which serves the expression of one's judgements ${ }^{42}$. The image, however, is the most important means by which emotions in news are created. It is the image that is the essence of a TV communication: without it, there is no television. Words play a secondary role. The persuasive function of the image results from the reception psychology. The image is treated as more reliable, and what is more - as true. The belief that what one sees is true is a priori. It has an imperative importance for the rhetoric of a communication because the polemical

${ }^{40}$ A. Pratkanis, E. Aronson, „Wiek propagandy. Używanie i nadużywanie perswazji na co dzień”, transl. J. Radzicki, M. Szuster, Wydawnictwo Naukowe PWN, Warsaw 2003, pp. 91-92.

${ }^{41}$ M. Mrozowski, „Media masowe. Władza, rozrywka i biznes”, Oficyna Wydawnicza Aspra JR, Warsaw 2001, pp. 309-314.

${ }^{42}$ B. Sobczak, ,Informowanie (nie)etyczne. O etyce dziennikarskiej i manipulacji w mediach”, in: „Retoryka i etyka”, ed. B. Sobczak, H. Zgółkowa, Wydawnictwo Poznańskie, Poznan 2009, pp. 195-196. 
ability declines ${ }^{43}$. One does not argue with what "can be seen with the naked eye". Apart from that, the images - because they look like the things they represent require less intellectual effort and are easier in reception. They also favour passivity and mindless reception ${ }^{44}$.

The choice and composition of images from which the takes, sequences and finally the whole footage are created, are an important instrument for influencing the audience. This way, it is possible to manipulate what is colloquially called the "temperature" of a communication - the degree of the recipient's emotional involvement in the message. The involvement will be lower the longer the shot in which the objects are filmed. In a long, full or American shot, the objects blend with the setting. However, the so called psychological shots (medium close-ups, close-ups, extreme close-ups) will raise the "temperature" of the communication because they draw attention, they force the focus on certain fragments. When it comes to filming people, the focus is on the eyes, mouth and brows, that is on the most important elements of the face in interpersonal communication ${ }^{45}$. Kazimierz Żórawsk ${ }^{46}$ claims that this regularity was already known by TV propaganda specialists in the times of the Polish People's Republic (PRL). Camera operators working on news magazines used to be given special instructions concerning which shots were applicable for the members of the government and The Polish United Workers' Party (Polish: Polska Zjednoczona Partia Robotnicza, PZPR) officials. "The General Secretary could be shot in medium close-ups, members of the politburo and the Prime Minister in medium shots, and the American shot was only for the ministers and members of the Central Committee of the Polish United Workers' Party" ${ }^{\prime 47}$. Even the camera motion plays an important part in the way the story about the world is created in news. Panoramic photography, by definition, makes the message objective, as it is a sequence of pieces of reality which uncover in front of the audience; a close-up, a lean-in, because it narrows the angle of observation, forces the recipient to focus and directs their attention to the selected element of the reality. A lean-out, however, enriches the image and changes the way it is assessed - what at the beginning seemed the most important becomes a part of a larger entity ${ }^{48}$. Shooting from above or from below is also crucial for the creation of emotions towards the described objects. The elevation of the camera in respect to the shot object reflects the attitude towards the person, it is a peculiar comment in itself. Shots from below increase the figure's dimensions,

\footnotetext{
${ }^{43}$ B. Reeves, C. Nass, op. cit., passim.

${ }^{44}$ K. Żórawski, „Długi stół. Skrypt dla dziennikarzy programów informacyjnych”, Telewizja Polska S.A., Warsaw 2004, p. 38; B. Reeves, C. Nass, op. cit., p. 68.

${ }^{45}$ B. Reeves, C. Nass, op. cit., p. 57.

${ }^{46} \mathrm{~K}$. Żórawski, op. cit., p. 45.

${ }^{47}$ Ibid.

${ }^{48}$ Ibid., pp. 46-47.
} 
which makes the audience perceive the person as dominant, strong and powerful, whereas shots from above shrink the shot object, and in case of a human being these shots reduce their importance ${ }^{49}$.

\section{Conclusion}

It is not essential to prove the constantly increasing role of mass media communications in public life. It is known that the media are not only an instrument of government control, without which contemporary democracy would be impossible, but the role of the media is also to create public discourses because - as is claimed by sociologists who investigate the sphere of public communication - what is not present in the media does not exist in the social consciousness ${ }^{50}$. Finally, the media, and especially television, because of their availability, are one of the fundamental sources of knowledge and entertainment. News plays an exceptional role in television. For the media broadcasters the news magazines are the flagship programmes - they constitute the brand name and the prestige of a TV station. For the recipients - especially during important moments in social life - news is one of the most important sources of information ${ }^{51}$. TV news functions in the media as one of the elements of the strategic operations of the media broadcasters who are focused on certain goals, including political and economic ones, as well as their public image. News is created as a response to certain events, it fulfils the need for information, but also creates the image of the world, it focuses attention on specific aspects of reality and their evaluation, news also confirms the importance or otherwise of events. It serves informational functions, but also creational, model-making, stimulating, evaluating and, finally, aesthetic ones. In order to achieve such aims, it is adequately constructed, including the character and the needs of the recipient, as well as the ethos of the broadcaster. News is thus a rhetorical act - intentional, deliberate, being a response to a certain situation (it is historically, socially and politically conditioned) and addressed to a specific audience.

\section{Bibliography}

Arystoteles, „Retoryka”, in: idem, „Retoryka. Retoryka dla Aleksandra. Poetyka”, transl. H. Podbielski, Wydawnictwo Naukowe PWN, Warsaw 2004.

${ }^{49}$ Ibid., p. 48.

${ }^{50}$ See: „Rytualny chaos. Studium dyskursu publicznego”, ed. M. Czyżewski, S. Kowalski, A. Piotrowski, Wydawnictwo Auteus, Cracow 1997.

${ }^{51}$ P. Francuz, „O rozumieniu telewizyjnych audycji informacyjnych”, Zeszyty Telewizyjne 2005, No. 8, p. 37. 
Bauer Z., „Gatunki dziennikarskie”, in: „Dziennikarstwo i świat mediów”, ed. Z. Bauer, E. Chudziński, Universitas, Cracow 2000, pp. 143-173.

Bitzer L.F., “The Rhetorical Situation”, Philosophy \& Rhetoric 1968, No. 1, pp. 1-14.

Bourdieu P., „O telewizji. Panowanie dziennikarstwa”, transl. K. Sztandar-Sztanderska, A. Ziółkowska, ed. M. Jacyno, Wydawnictwo Naukowe PWN, Warsaw 2009.

Campbell K.K., "Modern Rhetoric", in: "Encyclopedia of Rhetoric”, ed. T.O. Sloane, Oxford University Press, New York 2001.

Campbell K.K., Huxman S.S., Burkholder T.R., "The Rhetorical Act. Thinking, Speaking and Writing Critically”, Wadsworth, Belmont 2003.

Czyżewski M., Dunin K., Piotrowski A., „Cudze problemy. O ważności tego, co nieważne. Analiza dyskursu publicznego w Polsce", Wydawnictwa Akademickie i Profesjonalne, Warsaw 2010.

Francuz P., „O rozumieniu telewizyjnych audycji informacyjnych”, Zeszyty Telewizyjne 2005, No. 8, pp. 19-35.

Fras J., „Dziennikarski warsztat językowy”, Wydawnictwo Uniwersytetu Wrocławskiego, Wroclaw 1999.

Furman W., Kaliszewski A., Wolny-Zmorzyński K., „Gatunki dziennikarskie. Specyfika ich tworzenia i redagowania”, Wyższa Szkoła Zarządzania w Rzeszowie, Rzeszow 2000.

Gajda J., „Media w edukacji”, Oficyna Wydawnicza Impuls, Gdansk 2007.

Iłowiecki M., „Krzywe zwierciadło. O manipulacji w mediach”, Wydawnictwo Archidiecezji Lubelskiej Gaudium, Lublin 2003.

Jensen K.B., "The Social Semiotics of Mass Communication”, Sage Publications, London 1995.

Karwat M., „Medialna mitologia faktów”, in: „Współczesne oblicza mediów”, ed. J. Marszałek-Kawa, Wydawnictwo Adam Marszałek, Torun 2005, pp. 44-69.

Kudra A., „News jako funkcja”, Acta Universitatis Lodziensis. Folia Literaria Polonica 2010, No. 13, pp. 399-404.

Liberek J., „Informacja czy manipulacja? Jak Gazeta Wyborcza pisze o Kościele”, Więź 1992, No. 11, pp. 21-25.

Lisowska-Magdziarz M., „Media powszednie. Środki komunikowania masowego i szerokie paradygmaty medialne w życiu codziennym Polaków u progu XXI wieku", Wydawnictwo Uniwersytetu Jagiellońskiego, Cracow 2008.

Maslow A., „Motywacja i osobowość”, transl. J. Radzicki, Wydawnictwo Naukowe PWN, Warsaw 2006.

Maziarski J., „Informacja”, in: „Encyklopedia wiedzy o prasie”, ed. J. Maślanka, Ossolineum, Wroclaw 1976, pp. 107-109.

Miś L., „Demonstracje retoryczne w telewizyjnym programie informacyjnym «Fakty» - TVN”, in: „Sztuka perswazji. Socjologiczne, psychologiczne i lingwistyczne aspekty komunikowania perswazyjnego", ed. R. Karpiel, K. Leszczyńska, Zakład Wydawniczy Nomos, Cracow 2004, pp. 323-334.

Mrozowski M., „Media masowe. Władza, rozrywka i biznes”, Oficyna Wydawnicza Aspra JR, Warsaw 2001.

Mrozowski M., „Telewizyjne programy informacyjne - polskie i zagraniczne (analiza porównawcza)”, Studia Medioznawcze 2009, No. 3, pp. 27-49.

Palczewski M., „Cała prawda o newsie. Definicja - granice poznania - konteksty”, in: „Teorie komunikacji i mediów”, Vol. 4, ed. M. Graszewicz, J. Jastrzębski, Oficyna Wydawnicza Atut, Wroclaw 2011, pp. 53-73. 
Pisarek W., „Podstawy retoryki dziennikarskiej”, in: „Dziennikarstwo i świat mediów. Nowa edycja”, ed. Z. Bauer, E. Chudziński, 4. ed., rev., exp., up. ed., Universitas, Cracow 2008, pp. 361-377.

Pratkanis A., Aronson E., „Wiek propagandy. Używanie i nadużywanie perswazji na co dzień”, transl. J. Radzicki, M. Szuster, Wydawnictwo Naukowe PWN, Warsaw 2003.

Reeves B., Nass C., „Media i ludzie”, transl. H. Szczerkowska, Państwowy Instytut Wydawniczy, Warsaw 2000.

„Rytualny chaos. Studium dyskursu publicznego”, ed. M. Czyżewski, S. Kowalski, A. Piotrowski, Wydawnictwo Auteus, Cracow 1997.

Schramm W., "The Nature of News", Journalism Quarterly 1949, No. 26, pp. 259-269.

Silverstone R., "Television and Everyday Life", Routledge, London 1994, as cited in: S. Allan, „Kultura newsów”, transl. A. Sokołowska, Wydawnictwo Uniwersytetu Jagiellońskiego, Cracow 2004, p. 116.

Sobczak B., „Informowanie (nie)etyczne. O etyce dziennikarskiej i manipulacji w mediach”, in: „Retoryka i etyka”, ed. B. Sobczak, H. Zgółkowa, Wydawnictwo Poznańskie, Poznan 2009, pp. 183-201.

Szulczewski M., „Informacja”, in: „Teoria i praktyka dziennikarstwa. Wybrane zagadnienia”, ed. B. Golka, M. Kafel, Z. Mitzner, Państwowe Wydawnictwo Naukowe, Warsaw 1964, pp. 91-97.

Tetelowska I., „Informacja jako odrębny gatunek prasowy”, in: eadem, „Szkice prasoznawcze”, Ośrodek Badań Prasoznawczych, Cracow 1972.

Wasilewski J., Skibiński A., „Prowadzeni słowami. Retoryka motywacji w komunikacji publicznej”, Diffin, Warsaw 2008.

Whitehead J.L., "Factors Of Source Credibility”, Quarteley Journal of Speech 1968, No. 54, pp. 59-63.

Wojtak M., „Gatunki prasowe”, Wydawnictwo Uniwersytetu Marii Curie-Skłodowskiej, Lublin 2004.

Worsowicz M., „«Mam newsa!», czyli o problemie naukowców i marzeniu dziennikarzy”, in: „News wobec wyzwań XXI wieku”, ed. M. Palczewski, M. Worsowicz, Akademia Humanistyczno-Ekonomiczna, Lodz 2010, pp. 9-24.

Zwoliński A., „Słowo w relacjach społecznych”, WAM, Cracow 2003.

Żórawski K., „Długi stół. Skrypt dla dziennikarzy programów informacyjnych”, Telewizja Polska S.A., Warsaw 2004.

http://www.tnsglobal.pl/informacje/telewizja-trzyma-sie-mocno-nowe-urzadzenia-przynoszanowe-wzorce-ogladania-infografika/ [access: 21.03.2015].

http://wyborcza.pl/1,76842,15095765,Dla_60_proc__Polakow_TVP_jest_dobra_telewizja_publiczna_html [access: 21.03.2015]. 


\section{Barbara Sobczak}

\section{News as a Rhetorical Act}

\section{(Summary)}

This article presents television news as a rhetorical act. Television news is understood as an account of an event usually comprising of a short introduction and a few minutes of film footage (sometimes referred to as the editorial), created as a result of the work of reporters, broadcast on television, usually as one of the elements in the structure of a news magazine, but also as an element of the programme blocks of news television channels. Television news functions in the media as one of the elements of the strategic actions of media broadcasters, focused on specific purposes, including image-building and political and economic goals. News is created as a response to specific events, it fulfils the need for information, but also serves the creation of a certain image of the world, focusing attention on certain aspects of reality, evaluating it, persuading viewers of the importance or unimportance of certain events. It plays an informative, creative, conceptual, stimulating, evaluative and ultimately aesthetic role. In order to achieve these objectives it is appropriately constructed, taking into account the characteristics and needs of the recipient and the ethos of the broadcaster. In this sense, it is therefore a "rhetorical" act - intentional, deliberate, constituting a response to a specific situation (it is historically, socially and politically conditioned) and addressed to specific recipients.

Keywords: news, rhetorical act, television, persuasion, information. 